\title{
Aggregatibacter aphrophilus, Penicillinase Negative
}

National Cancer Institute

\section{Source}

National Cancer Institute. Aggregatibacter aphrophilus, Penicillinase Negative. NCI

Thesaurus. Code C119317.

Any bacterial species identified as Aggreg atibacter aphrophilus that does not produce the enzyme penicillinase. 